\title{
Using DNA barcoding to identify host-parasite interactions between cryptic species of goby (Coryphopterus: Gobiidae, Perciformes) and parasitic copepods (Pharodes tortugensis: Chondracanthidae, Cyclopoida)
}

\author{
GRAHAM E. FORRESTER ${ }^{1,2}$, MALACHY T. MCCAFFREY ${ }^{1,3}$, \\ KRISTINA X. TERPIS ${ }^{1,4} \&$ CHRISTOPHER E. LANE ${ }^{1,5}$ \\ ${ }^{1}$ Department of Natural Resources Science, University of Rhode Island, USA. \\ 2 ="gforrester@uri.edu; (1) https://orcid.org/0000-0003-2558-2767 \\ 3 "=mmccaffrey17@my.uri.edu; ○https://orcid.org/0000-0003-1157-7182 \\ ${ }^{4}$ "="kristina_terpis@uri.edu; @ ittps://orcid.org/0000-0003-4496-8526 \\ 5 I"clane@uri.edu; @ichttps://orcid.org/0000-0003-2558-2767
}

\begin{abstract}
Previous work, using morphological characters, identified a generalist copepod parasite (Pharodes tortugensis) at high prevalence on two common gobies (Coryphopterus glaucofraenum and C. dicrus) in the British Virgin Islands (BVI). DNA barcoding subsequently revealed C. glaucofraenum to be three morphologically similar species (C. glaucofraenum, C. venezuelae and C. tortugae), casting doubt on host identities in the BVI and the classification of the parasite as a single species. Mitochondrial cytochrome c oxidase subunit I (COI) data from 67 gobies in the BVI showed that, in addition to C. dicrus, host gobies were a mix of $C$. glaucofraenum and $C$. venezuelae, while $C$. tortugae was unexpectedly absent from the study area. COI data $(\mathrm{n}=70)$ indicated that the copepod infecting all three hosts was a single species, almost certainly P. tortugensis. The pharodes-coryphopterus interaction has a strong impact on host dynamics in the BVI, and a revised understanding of these dynamics must account for any differences among the three newly confirmed hosts in transmission of, and susceptibility to, the shared parasite. No other infected hosts were discovered at our sites, but $P$. tortugensis is reportedly widespread and infects 12 additional host species elsewhere. Further DNA barcoding is thus needed to test whether $P$. tortugensis is truly a widespread generalist, or instead represents a group of more specialized cryptic species.
\end{abstract}

Key words: British Virgin Islands, Caribbean, COI sequences, host-specificity, new geographic record

\section{Introduction}

Species are basic units of study for ecologists, and much of ecological theory specifies how species interact with one another as parasites and hosts, predators and prey, competitors and facilitators. The classification of species is, however, constantly evolving as taxonomists identify new species and reevaluate the relationships of those already identified. Traditional methods of classifying species, based on shared morphological features, are increasingly augmented by genetic methods that identify species using standardized regions of DNA (DNA barcoding) (Marshall 2005). DNA barcoding has revealed many cryptic species that lack obvious phenotypic differences, and so were previously classified as one taxon (Trontelj \& Fišer 2010). Improvements in taxonomy can thus help clarify the identities of species that participate in ecological interactions (Bickford et al. 2007).

Host-specificity, the extent to which parasites infect different host species (Poulin et al. 2011), is a fundamental feature of host-parasite interactions and accurately identifying the participants in host-parasite interactions has wideranging implications. Ecological implications range from the accuracy of biological diversity estimates to predicting the transmission of specific diseases (Poulin 2014). For example, attempts to control a pathogenic parasite may be thwarted if an unrecognized host species serves as a reservoir for the parasite even if it is extinct in recognized hosts (Besansky 1999; Haydon 2002). In addition, the impacts of invasive parasites can escape detection if invaders are mistaken for native species or other invaders that are morphologically similar (Goedknegt et al. 2018). Lastly, tak- 
ing advantage of host-parasite interactions for biological pest control typically relies on accurately characterizing a specialist relationship between the pathogen and its host (Bickford et al. 2007).

The discovery of cryptic parasite and host species (Nadler \& De Leon 2011) has spurred re-evaluation of many host-parasite interactions (Banks \& Paterson 2005; Costello 2016; de León \& Nadler 2010). It has been argued that the number of hosts occupied by a given parasite is often underestimated (Costello 2016). Supporting this hypothesis are examples in which the range of hosts infected by parasites was higher than previously thought because a presumed single host was subsequently found to represent several cryptic species (e.g. Westram et al. 2011). On the other hand, there are also cases when a single generalist parasite believed to infect multiple hosts was, in fact, a complex of cryptic specialist parasite species each infecting a subset of the hosts (Poulin \& Keeney 2008; e.g. Smith et al. 2006).

In this study, we clarify a host-parasite interaction in which both hosts and parasites include potentially cryptic species. The parasite is a copepod, Pharodes tortugensis Wilson, that was described using morphological characters (Ho 1971) and has, to the best of our knowledge, not been studied genetically. P. tortugensis infects the branchial chamber of fishes and was described from fishes in museum collections that included several small gobies and blennies from the western Atlantic, plus a few larger reef-associated fishes (Table 1). During field surveys of potential hosts in the British Virgin Islands (BVI) from 1994-2016, P. tortugensis was found only on three coryphopterus gobies that inhabit mixed sand and reef habitat (Table 1). The identification of $P$. tortugensis (Petrik-Finley 2005) was confirmed by the author of the species (Dr. Ju-she Ho, University of California Long Beach, personal communication 2002). Two common gobies, Coryphopterus glaucofraenum Gill and C. dicrus Böhlke \& Robins were infected frequently (Finley \& Forrester 2003; Petrik-Finley 2005). Coryphopterus eidolon Böhlke \& Robins was also infected, but this goby is rare in the BVI and so the prevalence of infection was not estimated accurately (PetrikFinley 2005).

Since these BVI field surveys, DNA barcoding has led to the discovery of new Coryphopterus species and the re-examination of others, including C. glaucofraenum, one of the species hosting P. tortugensis in the BVI (Baldwin et al. 2009; Baldwin \& Robertson 2015; Thacker \& Cole 2002; Victor 2007, 2008; Volk et al. 2020). These studies resolved longstanding debate over whether Coryphopterus tortugae (Jordan) and Coryphopterus venezuelae Cervigón were separate from C. glaucofraenum and supported the validity of each as distinct species (Böhlke \& Robins 1960; Cervigón 1994; Garzón-Ferreira \& Arturo Acero 1990; Thacker \& Cole 2002). Victor (2008) also described a fourth species Coryphopterus bol, but subsequent work suggests $C$. bol may be a junior synonym of $C$. venezuelae (Baldwin et al. 2009; Baldwin \& Robertson 2015). Although C. glaucofraenum, C. tortugae and C. venezuelae are distinct genetically and have slightly different markings, there remains uncertainty over whether they can be reliably identified in the field using visual markings (Robertson \& Van Tassell 2019; Victor 2015). Their respective geographical distributions, habitat use and ecological interactions also require reconsideration (Baldwin \& Robertson 2015; Greenfield \& Johnson 1999; Robertson \& Van Tassell 2019; Victor 2008, 2015).

Based on the taxonomic status of hosts and parasites prior to 2007, it was argued that ecologically important pharodes-coryphopterus interactions in the BVI involve one parasite (P. tortugensis) infecting two common hosts (C. glaucofraenum and C. dicrus) and one rare host (C. eidolon) (Finley \& Forrester 2003; Forrester et al. 2019; Forrester \& Finley 2006; Petrik-Finley 2005). The revised classification of $C$. glaucofraenum suggests that this host may represent up to three cryptic host species. This discovery also raises the possibility that, rather than being a single generalist parasite, $P$. tortugensis might actually consist of multiple cryptic parasite species, some of which could be more specialized than previously thought. The objective of this study was thus to combine DNA barcoding with analysis of markings visible in the field to clarify the identities of host and parasite species taking part in the pharodes-coryphopterus interaction in the British Virgin Islands.

\section{Methods}

\section{Study sites and collection of specimens}

Fish were collected at two fringing reef sites near Guana Island $\left(18^{\circ} 28^{\prime} \mathrm{N}, 64^{\circ} 34^{\prime} \mathrm{W}\right)$ in the British Virgin Islands at water depths of 5-8 m. The two sites were selected to test for segregation of the gobies by habitat. (1) Harris Ghut comprises white coral sand with a rippled surface, interspersed with patches of coral and limestone reef. (2) White Bay West consists of finer muddy sand interspersed with limestone reef, coral rubble, and seagrass. The finer sedi- 
ment at White Bay West, slightly higher turbidity, and its inner position within the bay indicates lower exposure to wave energy and currents than Harris Ghut (Folk 1980). Harris Ghut provides habitat hypothesized to be favoured by $C$. tortugae, whereas C. glaucofraenum is hypothesized to prefer the sheltered habitat found in White Bay West (Greenfield \& Johnson 1999; Victor 2015).

We collected 145 gobies for analysis. Each goby was digitally photographed in its natural habitat by a diver prior to capture. Gobies were then collected using the anaesthetic Quinaldine and a hand net, placed in a clear plastic bag then photographed a second time while still underwater. Because $P$. tortugensis might be host-specific and infect some goby species, but not others, both infected and uninfected gobies were collected $(\mathrm{n}=85$ uninfected, $\mathrm{n}=60$ infected). Gobies infected with $P$. tortugensis can be diagnosed visually by divers because they have a distinctive distension of the operculum (Finley \& Forrester 2003; Forrester et al. 2019; Petrik-Finley 2005). Our collections focused on individuals suspected to be $C$. glaucofraenum, $C$. tortugae and $C$. venezuelae, but we also collected a small sample of $C$. dicrus $(\mathrm{n}=7)$ because it is also a common host of $P$. tortugensis. While collecting, we also searched for other gobies and blennies with distended opercula that might also be infected with P. tortugensis (Table 1), but none were encountered.

TABLE 1. Hosts of P. tortugensis in the BVI discovered using DNA barcoding in this study (BVI genetic ID) and previously using morphological characters (BVI morphological ID) (Petrik-Finley 2005), plus hosts identified using morphological characters in other areas (Horton et al. 2020). Listed are fish species on which P. tortugensis was found (yes) or not found (no), or no data available (-).

\begin{tabular}{|c|c|c|c|c|c|}
\hline Host Family & Host species & $\begin{array}{l}\text { Host common } \\
\text { name }\end{array}$ & $\begin{array}{l}\text { BVI } \\
\text { genetic ID }\end{array}$ & $\begin{array}{l}\text { BVI } \\
\text { morphological ID }\end{array}$ & $\begin{array}{l}\text { Other sites } \\
\text { morphological ID }\end{array}$ \\
\hline Gobiidae & $\begin{array}{l}\text { Coryphopterus } \\
\text { glaucofraenum }\end{array}$ & bridled goby & yes & yes & - \\
\hline Gobiidae & $\begin{array}{l}\text { Coryphopterus } \\
\text { venezuelae }\end{array}$ & $\begin{array}{l}\text { sand-canyon } \\
\text { goby }\end{array}$ & yes & yes & - \\
\hline Gobiidae & Coryphopterus dicrus & colon goby & yes & yes & - \\
\hline Gobiidae & Coryphopterus eidolon & pallid goby & - & yes & - \\
\hline Gobiidae & $\begin{array}{l}\text { Coryphopterus } \\
\text { personatus }\end{array}$ & masked goby & - & no & - \\
\hline Gobiidae & Coryphopterus hyalinus & glass goby & - & no & - \\
\hline Gobiidae & Gnatholepis thompsoni & Goldspot goby & - & no & - \\
\hline Gobiidae & Tigrigobius multifasciatus & $\begin{array}{l}\text { Greenbanded } \\
\text { goby }\end{array}$ & - & no & - \\
\hline Gobiidae & Bathygobius soporator & frillfin goby & - & no & yes \\
\hline Gobiidae & Tigrigobius saucrus & leopard goby & - & no & yes \\
\hline Gobiidae & Elacatinus chancei & shortstripe goby & - & no & yes \\
\hline Gobiidae & Elacatinus evelynae & sharknose goby & - & no & yes \\
\hline Gobiidae & Elacatinus horsti & yellowline goby & - & no & yes \\
\hline Gobiidae & Elacatinus illecebrosus & barsnout goby & - & - & yes \\
\hline Blenniidae & $\begin{array}{l}\text { Hypleurochilus } \\
\text { aequipinnis }\end{array}$ & oyster blenny & - & - & yes \\
\hline Blenniidae & Scartella cristata & Molly Miller & - & - & yes \\
\hline Blenniidae & Malacoctenus boehlkei & diamond blenny & - & no & - \\
\hline Blenniidae & Malacoctenus macropus & rosy blenny & - & no & - \\
\hline Blenniidae & Parablennius marmoreus & seaweed blenny & - & no & - \\
\hline Belonidae & Ablennes hians & flat needlefish & - & - & yes \\
\hline Sparidae & Calamus bajonado & jolthead porgy & - & - & yes \\
\hline Carcharhinidae & $\begin{array}{l}\text { Rhizoprionodon } \\
\text { terraenovae }\end{array}$ & $\begin{array}{l}\text { Atlantic sharp- } \\
\text { nose shark }\end{array}$ & - & - & yes \\
\hline
\end{tabular}


After being photographed, gobies were euthanized using Quinaldine and preserved in 95\% ethanol. Copepods were removed from parasitized gobies under a dissecting microscope. Consistent with previous work (Petrik-Finley 2005), female copepods were found attached to the ventral surface of the branchial chamber, whereas males and juveniles were found within the branchial chamber, on the gill arches and on the underside of the operculum. A typical infection consisted of one or two large females, plus a few smaller males and juveniles (mean $=4$ copepods per goby, range $=1-17)$. All dissected copepods were preserved in $100 \mu \mathrm{L}$ of $100 \%$ ethanol and stored at $-20^{\circ} \mathrm{C}$.

\section{Identifying gobies using visual markings}

Using published keys and guides to morphological characters and markings that distinguish Coryphopterus gobies (Baldwin \& Robertson 2015; Robertson \& Van Tassell 2019; Victor 2015), we selected three pigment markings that could be discerned by divers in the field and were visible on the photographs of the gobies (Table 2). Using the photographs taken in the field, each goby was identified to species using these three characters (hereafter referred to as its visual ID).

TABLE 2. Visual pigment markings used to identify the three morphologically similar gobies from photos and in the field on SCUBA. Coryphopterus dicrus is readily distinguishable from the other species, and so is not included.

\begin{tabular}{llll}
\hline Location of pigment marks & C. glaucofraenum & C. venezuelae & C. tortugae \\
\hline Behind opercle & $\begin{array}{l}\text { Dark marking, two peaks, } \\
\text { usually triangular }\end{array}$ & $\begin{array}{l}\text { Dark marking, single peak, triangular } \\
\text { or circular }\end{array}$ & $\begin{array}{l}\text { Dark marking, single } \\
\text { peak, triangular or } \\
\text { circular }\end{array}$ \\
Base of pectoral fin & No pigment marking & $\begin{array}{l}\text { Ventral marking, circular or rectangular, } \\
\text { yellow or orange in colour }\end{array}$ & No pigment marking \\
Base of caudal fin & Two circular spots, & Variable; central bar or two colon-like & Central bar, dark in \\
& colon-like, dark in colour & spots or vertical dumbell or & colour \\
\hline
\end{tabular}

We also tested whether C. glaucofraenum could be distinguished from C. tortugae, and possibly C. venezuelae, based on body shape. Garzón-Ferreira and Acero (1990) showed that the ratio of body depth to body length was higher in C. glaucofraenum (20.5-26.2\%) than C. tortugae (19.5-22.5\%), although the individuals they described as C. tortugae also included C. venezuelae (Victor 2008). Using photographs in which gobies were roughly perpendicular to the frame, we measured the standard body length (SL) and body depth, measured at the base of the dorsal fin spines, of each goby (using the image analysis software Fiji, Schindelin et al. 2012). Because infection alters body shape (Petrik-Finley 2005), body depth was measured only for uninfected gobies $(\mathrm{n}=80)$. The distribution of body depths (as a \% of SL) was compared among species using a Kruskal-Wallis test.

\section{DNA extraction, amplification and sequencing}

The right pectoral fin, caudal fin, or the right operculum were taken as tissue samples from gobies, and entire copepods were used for DNA extraction. DNA was extracted using the NucleoSpin ${ }^{\circledR}$ Tissue kits (MachereyNagel) following the manufacturer protocol. A 658 base pair region of the mitochondrial cytochrome c oxidase subunit I (COI) gene was amplified using the primers LCO1490 5'-GGTCAACAAATCATAAAGATATTGG-3' and HCO2198 5'-TAAACTTCAGGGTGACCAAAAAATCA-3' (Folmer et al. 1994). All PCR products were amplified using TaKaRa ExTaq in a final volume of $50 \mu \mathrm{L}$ consisting of $37.75 \mu \mathrm{L}$ purified water, $5 \mu \mathrm{L} 10 \mathrm{X}$ buffer solution, $4 \mu \mathrm{L}$ dNTP, $1 \mu \mathrm{L}$ of each primer ([50 $\mu \mathrm{M}]), 1 \mu \mathrm{L}$ sample gDNA, and $0.25 \mu \mathrm{L}$ ex-Taq DNA polymerase. Polymerase Chain Reactions (PCRs) were run in an Eppendorf 6325 Vapo.Protect MasterCycler Pro-S under the following thermal protocol: initial denaturation at $94 \square$ for $2 \mathrm{~min}, 38$ cycles of denaturation at $94 \square$ for $30 \mathrm{~s}$, annealing at $50 \square$ for $25 \mathrm{~s}$, and extension at $72 \square$ for $30 \mathrm{~s}$, with a final extension of $72 \square$ for $5 \mathrm{~min}$. Goby samples that did not amplify using LCO/HCO primers were amplified using Fish F1 and Fish R1 (Ward et al. 2005) using the following PCR cycle: initial denaturation at $94 \square$ for $2 \mathrm{~min}, 33$ cycles of denaturation at $94 \square$ for $30 \mathrm{~s}$, annealing at $55 \square$ for $30 \mathrm{~s}$, and extension at $72 \square$ for $60 \mathrm{~s}$, with a final extension of $72 \square$ for $5 \mathrm{~min}$. Copepod samples that did not amplify or were contaminated with fish DNA were amplified using Cope1489F and Cope2189R (Bucklin et al. 2010 ) using the following thermal protocol: initial denaturation at $94 \square$ for $2 \mathrm{~min}, 33$ cycles of denaturation at $94 \square$ for $30 \mathrm{~s}$, annealing at $45 \square$ for $30 \mathrm{~s}$, and extension at $72 \square$ for $60 \mathrm{~s}$, with a final extension of $72 \square$ for 5 min. PCR 
products were cleaned using the NucleoSpin Gel and PCR Clean-up kit (Machery-Nagel) and Sanger sequencing was performed at the RI Genomics and Sequencing Center.

DNA from 67 gobies was sequenced, of which 39 were infected with copepods. Seventy copepods were sequenced from the 39 infected gobies. In order to test whether more than one parasite species could infect a single host, two copepods were sequenced from most gobies $(n=31)$, but for some $(n=8)$ just one copepod was sequenced.

Bidirectional reads were assembled (excluding the 5' and 3' primer regions) using Geneious (vrs9.1.8). BLAST searches were performed to confirm the identity of all sequences. The mtCOI barcodes were aligned using MAFFT (Katoh et al. 2019) with additional data from GenBank and the complete alignment was trimmed to $658 \mathrm{bp}$. The verified sequences were submitted to the National Center for Biotechnology Information (NCBI, see Appendix Table 1). Maximum likelihood phylogenetic analysis was conducted under the GTR $+\mathrm{I}+\mathrm{G}$ model using IQ-Tree (Nguyen et al. 2015). Node support was calculated using 1000 nonparametric bootstrap replicates. Based on the phylogenetic analysis, each unknown sample was assigned a species identity (hereafter sequence ID; Appendix Table 1).

\section{Probability of a species being present but not sampled}

After identifying the species in our samples, we assessed how confident we could be in concluding that that other species not collected were truly absent. To make this estimate, we considered each sample a binomial trial in which an undetected species is found or not (Bland 2013). The observed proportion of undetected species ( $p$ ) in our samples was thus zero, and we calculated the upper $95 \%$ confidence interval for this estimate of $p$ given our sample size (following McDonald 2014).

\section{Data availability}

The raw data used in this study, including digital images used for goby visual IDs, are archived online (https://doi. org/10.5061/dryad.h18931zjs). The GenBank Accession numbers are reported in Tables 4-5 and Appendix Table 1.

\section{Results}

\section{Identity and habitat use of gobies present in the study area}

DNA barcoding revealed three distinct genetic lineages within our goby samples (Figure 1), each with low withingroup sequence divergences $(<1.5 \%)$ typical of intraspecific variation (Ward et al. 2009). The lineages matched those published for C. glaucofraenum, C. venezuelae and C. dicrus using neighbour-joining trees constructed with COI sequences (Baldwin et al. 2009; Baldwin \& Robertson 2015; Victor 2008).

All but one of the 145 gobies in our field samples could be assigned a visual ID using the three characters in Table 2. There was $100 \%$ agreement between the visual IDs and sequence IDs of the 67 gobies identified using both methods (Table 3). C. glaucofraenum and C. venezuelae also tended to differ in body depth (Kruskal-Wallis test; $H=20.62, p<0.0001)$. C. venezuelae were more slender than $C$. glaucofraenum, although there was not complete separation in body depths between the two species (Figure 2). The few $C$. dicrus measured $(\mathrm{n}=3)$ ranged in body depth from 22.0-23.1\%, and so overlapped in body depth with C. glaucofraenum (Figure 2).

TABLE 3. Match between assignment of gobies to species using COI sequences versus visual characters.

\begin{tabular}{llcccc}
\hline & & \multicolumn{4}{c}{ Sequence ID } \\
\cline { 3 - 6 } & & C. glaucofraenum & C. venezuelae & C. dicrus & C. tortugae \\
\hline \multirow{2}{*}{ Visual ID } & C. glaucofraenum & 15 & 0 & 0 & 0 \\
& C. venezuelae & 0 & 45 & 0 & 0 \\
& C. dicrus & 0 & 0 & 7 & 0 \\
& C. tortugae & 0 & 0 & 0 & 0 \\
\hline
\end{tabular}

We did not collect any C. tortugae and our sample provides reasonable confidence of its absence (estimated proportion of gobies that are $C$. tortugae $=0,95 \% \mathrm{CI}=0$ to $0.026, \mathrm{n}=145$ ). A review of photographs taken during other studies since $1994(\mathrm{n}=53)$ also revealed no C. tortugae, further supporting its absence (e.g., Finley \& Forrester 2003; Forrester 1995, 1999; Forrester et al. 2011; Forrester \& Finley 2006; Forrester \& Steele 2000, 2004). 
C. venezuelae and C. glaucofraenum $(\mathrm{n}=138)$ appeared to segregate by habitat. Only C. venezuelae was observed at Harris Ghut, where the habitat was white sand and patchy coral reef, whereas a mix of $C$. glaucofraenum and C. venezuelae ( $73 \%$ and $27 \%$ respectively) were found at White Bay West, where the substratum was silty sand, rubble, and seagrass.

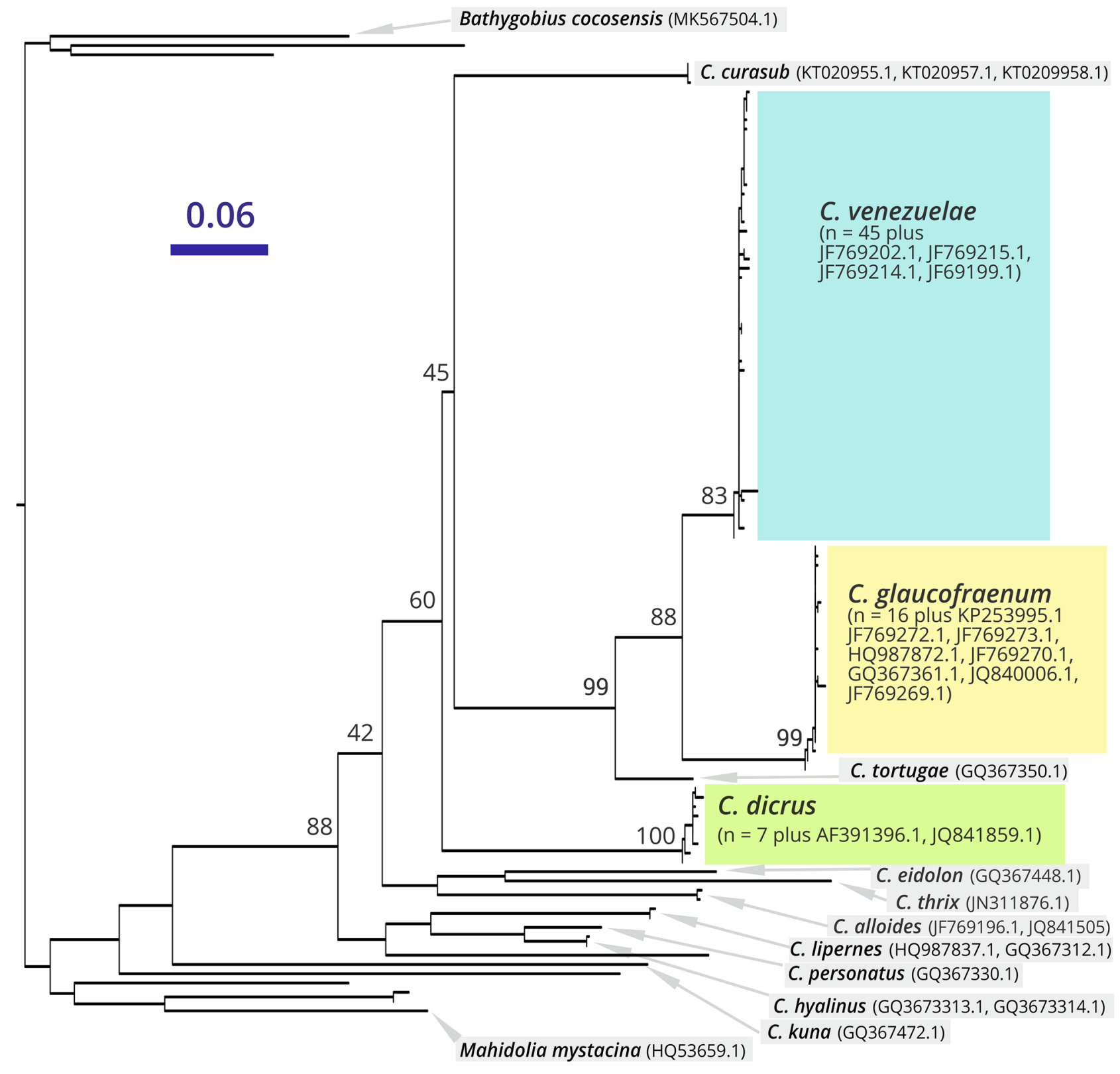

FIGURE 1. Maximum likelihood tree derived from COI sequences of our goby samples plus voucher sequences from all Coryphopterus species except $C$. punctipectophorus. Voucher sequences are identified by GenBank sequence ID. Sequences from several other goby species are included as outgroups (not all are identified in the figure; see Table 4 for a list). Support values for bipartitions are indicated, and divergence represented by scale bar $=6 \%$. 
TABLE 4. List of goby samples from previous studies included in Figure 1.

\begin{tabular}{|c|c|c|c|c|}
\hline $\begin{array}{l}\text { GenBank } \\
\text { Accession \# }\end{array}$ & Genus & Species & $\begin{array}{l}\text { Voucher or } \\
\text { isolate }\end{array}$ & Voucher \# \\
\hline JF769196 & Coryphopterus & alloides & voucher & n7530bca160 \\
\hline JQ841505 & Coryphopterus & alloides & voucher & BZLW8268 \\
\hline JF769199 & Coryphopterus & bol & voucher & n762acn310 \\
\hline JF769202 & Coryphopterus & bol & voucher & pr785acb245 \\
\hline JF769214 & Coryphopterus & bol & voucher & n7530acn186 \\
\hline JF769215 & Coryphopterus & bol & voucher & n7530acn 187 \\
\hline KT020955 & Coryphopterus & curasub & voucher & USNM 406373 \\
\hline KT020957 & Coryphopterus & curasub & voucher & USNM 430037 \\
\hline КT020958 & Coryphopterus & curasub & voucher & USNM 430019 \\
\hline AF391396 & Coryphopterus & dicrus & isolate & CORYPUN \\
\hline JQ841859 & Coryphopterus & dicrus & voucher & FCC8121 \\
\hline GQ367448 & Coryphopterus & eidolon & voucher & NMNH Fish BZE4089 \\
\hline GQ367361 & Coryphopterus & glaucofraenum & voucher & NMNH Fish BZE7769 \\
\hline HQ987872 & Coryphopterus & glaucofraenum & voucher & cn10c69 \\
\hline JF769269 & Coryphopterus & glaucofraenum & voucher & pr784bcg159 \\
\hline JF769270 & Coryphopterus & glaucofraenum & voucher & $\operatorname{pr} 784 \mathrm{bcg} 195$ \\
\hline JF769272 & Coryphopterus & glaucofraenum & voucher & st307acgx260 \\
\hline JF769273 & Coryphopterus & glaucofraenum & voucher & st307acx300 \\
\hline JQ840006 & Coryphopterus & glaucofraenum & voucher & BZLW4116 \\
\hline JQ840463 & Coryphopterus & glaucofraenum & voucher & BZLW5226 \\
\hline KP253995 & Coryphopterus & glaucofraenum & voucher & FTP 12 \\
\hline GQ367313 & Coryphopterus & hyalinus & voucher & NMNH Fish BZE4511 \\
\hline GQ367314 & Coryphopterus & hyalinus & voucher & NMNH Fish BZE4512 \\
\hline GQ367472 & Coryphopterus & kuna & voucher & NMNH Fish BZE6049 \\
\hline GQ367312 & Coryphopterus & lipernes & voucher & NMNH Fish CUR8327 \\
\hline HQ987837 & Coryphopterus & lipernes & voucher & $\operatorname{pr} 784 \mathrm{acl} 76$ \\
\hline GQ367330 & Coryphopterus & personatus & voucher & NMNH Fish BZE7163 \\
\hline JN311876 & Coryphopterus & thrix & voucher & $\mathrm{n} 7530 \mathrm{bc} 157$ \\
\hline GQ367350 & Coryphopterus & tortugae & voucher & JVT77256 \\
\hline FJ583288 & Cryptocentrus & leptocephalus & voucher & BIOUG CAN HLC 11903 \\
\hline HQ536660 & Cryptocentrus & leptocephalus & isolate & C199 \\
\hline MK567504 & Bathygobius & cocosensis & voucher & USNM FISH 442433 \\
\hline MK572079 & Brachygobius & nunus & & \\
\hline JQ349994 & Fusigobius & $s p$ & voucher & BOLD AAU4384 \\
\hline MG450087 & Lophogobius & cyprinoides & voucher & BACQ \\
\hline HQ536659 & Mahidolia & mystacina & isolate & $\mathrm{C} 182$ \\
\hline HQ945926 & Oligolepis & keiensis & voucher & ADC10 \\
\hline MH674047 & Tridentiger & barbatus & isolate & KL175 \\
\hline
\end{tabular}




$$
(n=3) \quad(n=11) \quad(n=66)
$$

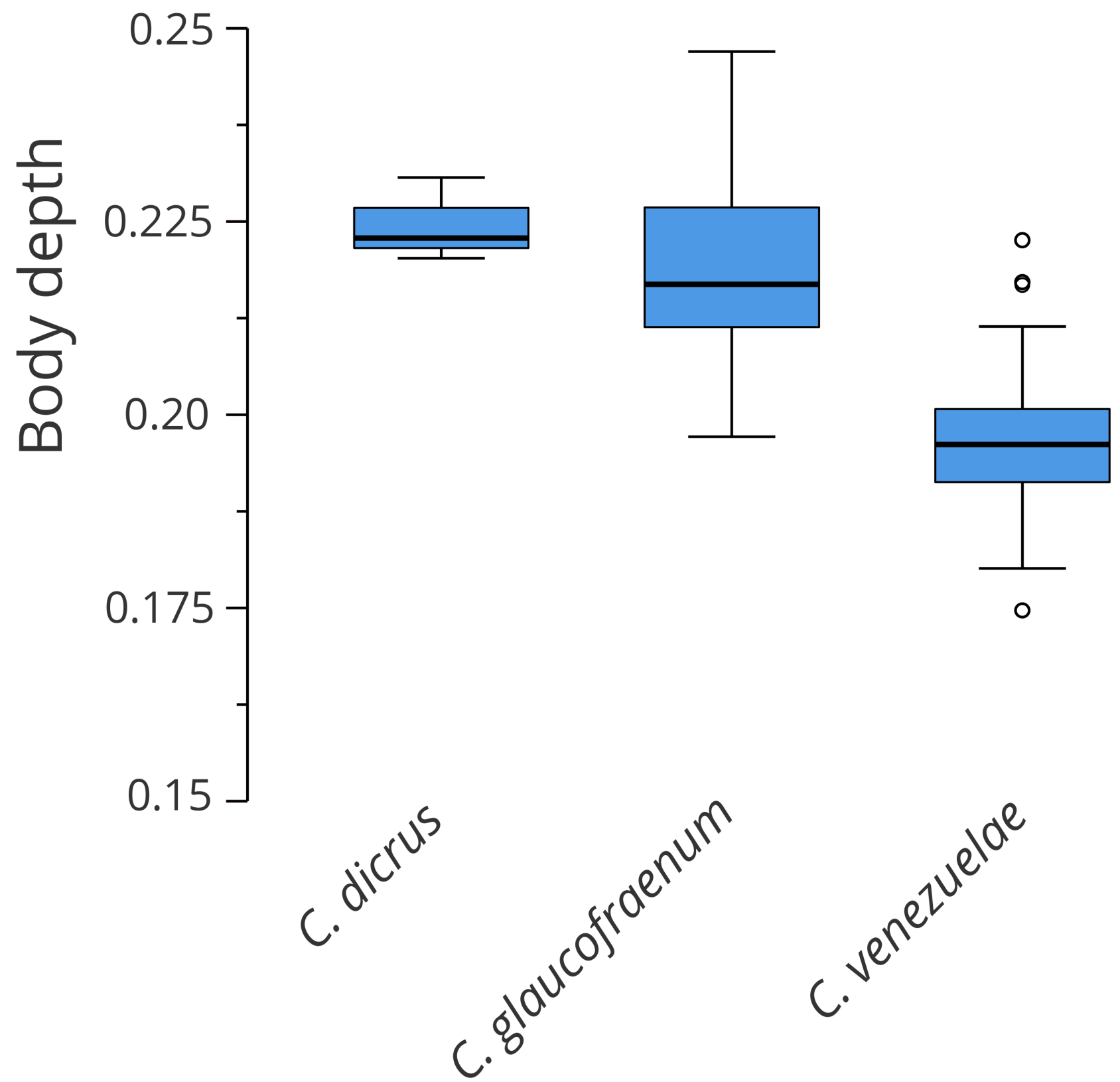

FIGURE 2. Differences in body depth between goby species. A boxplot of body depth (as a \% of body length in SL) for the three gobies, with sample sizes in parentheses. For the boxplot: box boundaries represent 25 th and 75 th percentiles respectively; line inside box indicates the median, lower and upper error lines indicate 10th and 90th percentiles respectively, and circles show data falling outside 10th and 90th percentiles. 
TABLE 5. List of copepod samples from previous studies included in Figure 3.

\begin{tabular}{|c|c|c|c|c|}
\hline $\begin{array}{l}\text { GenBank } \\
\text { Accession \# }\end{array}$ & Family & Genus & Species & $\begin{array}{l}\text { Voucher or } \\
\text { accession ID \# }\end{array}$ \\
\hline KT030281 & Clausidiidae & Conchyliurus & quintus & LEGO-POE007 \\
\hline KR049027 & Clausidiidae & Hemicyclops & tanakai & LEGO-POE050 \\
\hline KR049025 & Clausidiidae & Hemicyclops & gomsoensis & LEGO-POE009 \\
\hline MK370310 & Giselinidae & & $s p$ & 723DZMB \\
\hline MN854870 & Ergasilidae & Acusicola & sp. 1 & 774AcitAsL \\
\hline MN854851 & Ergasilidae & Acusicola & sp. 1 & 623AcitAsL \\
\hline MF651988 & Ergasilidae & Ergasilus & jaraquensis & 193762 \\
\hline KR049036 & Ergasilidae & Ergasilus & wilsoni & LEGO-POE014 \\
\hline KR049037 & Ergasilidae & Neoergasilus & japonicus & LEGO-POE015 \\
\hline KR049047 & Rhynchomolgidae & Zamolgus & cavernularius & LEGO-POE028 \\
\hline MH374723 & Rhynchomolgidae & Paradoridicola & sp. 1 & \\
\hline GBCRO6094-19 & Anchimolgidae & Prionomolgus & sp. 1 & МH374772 \\
\hline GBCRO6097-19 & Anchimolgidae & Prionomolgus & sp. 2 & MH374685 \\
\hline GBCRO6118-19 & Anchimolgidae & Schedomolgus & sp. 1 & MH374682 \\
\hline GBCRO6186-19 & Anchimolgidae & Schedomolgus & sp. 1 & МH374839 \\
\hline KR049023 & Chondracanthidae & Chondracanthus & distortus & LEGOPOE006 \\
\hline GBCRO110819 & Chondracanthidae & Chondracanthus & distortus & KR049023 \\
\hline GBCRO111119 & Chondracanthidae & Chondracanthus & $z e i$ & KR049033 \\
\hline KR049033 & Chondracanthidae & Chondracanthus & $z e i$ & LEGOPOE042 \\
\hline BNSC59815 & Chondracanthidae & Chondracanthus & lophii & KT208406 \\
\hline BNSC59515 & Chondracanthidae & Chondracanthus & lophii & KT209368 \\
\hline KR049022 & Chondracanthidae & Brachiochondria & pinguis & LEGOPOE005 \\
\hline MH242703 & Chondracanthidae & Chondracanthus & irregularis & BFHL2227 \\
\hline MN138366 & Chondracanthidae & Acanthochondria & rectangularis & ВMBM0758 \\
\hline BNSCP09714 & Chondracanthidae & Chondracanthus & merluccii & KT208610 \\
\hline BNSCP09914 & Chondracanthidae & Chondracanthus & merluccii & KT208757 \\
\hline BNSCP09814 & Chondracanthidae & Chondracanthus & merluccii & KT209334 \\
\hline KR049021 & Chondracanthidae & Acanthochondria & tchangi & LEGOPOE004 \\
\hline KR049020 & Chondracanthidae & Acanthochondria & spirigera & LEGOPOE003 \\
\hline
\end{tabular}

Identity of the parasitic copepod

DNA barcoding revealed just one genetic lineage within our copepod samples, and the extremely low within-group sequence divergence $(<0.5 \%)$ suggests they are a single species (Figure 3 ). Our sample provides reasonable confidence that additional species are absent (estimated proportion of copepods that are other species $=0,95 \% \mathrm{CI}=0$ to $0.051, \mathrm{n}=69$ ). We thus found no evidence for cryptic copepod species specialized on one or more of these goby hosts, nor any segregation of copepods by host habitat. 


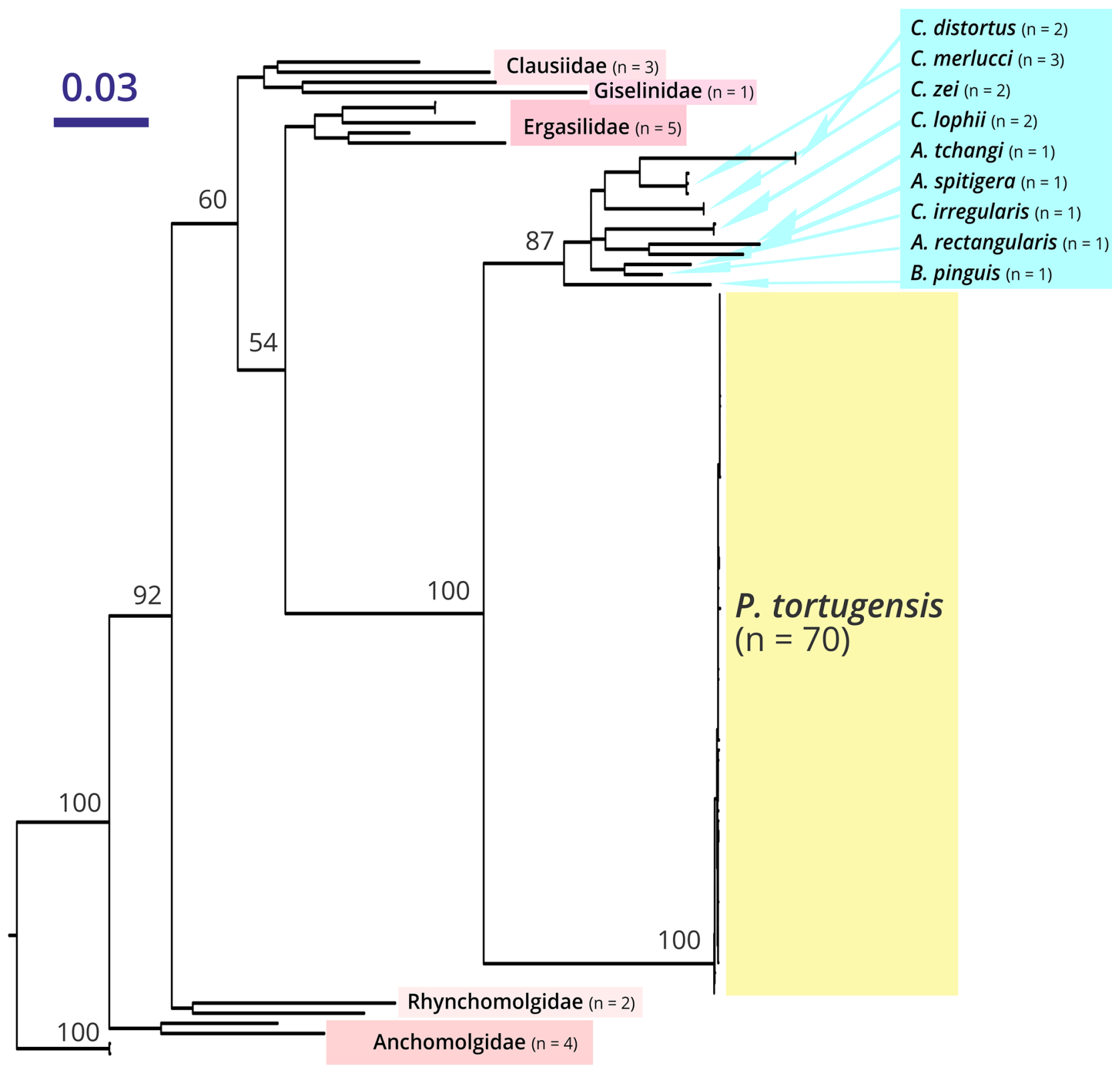

FIGURE 3. Maximum likelihood tree derived from COI sequences of our copepod samples (labeled as P. tortugensis) plus voucher sequences from related copepods in the suborder Ergasilida (see Table 5 for a list). Sequences of copepods confamilial to P. tortugenis (Chondracanthidae) are labelled to species (and shaded blue in the online colour version), and members other taxa are labeled to family (and shaded pink in the colour online version). Support values for bipartitions are indicated, and divergence represented by dark blue scale bar $=3 \%$.

\section{Discussion}

\section{Clarified pharodes-coryphopterus interactions in the BVI}

The three coryphopterus gobies previously grouped as $C$. glaucofraenum have each been identified using COI sequences at several locations across the tropical western Atlantic (Baldwin et al. 2009; Baldwin \& Robertson 2015; Victor 2008; Volk et al. 2020). Our results extend the confirmed ranges of $C$. glaucofraenum and $C$. venezuelae to the BVI and, because these species are widespread in the region, their presence was not surprising. The apparent absence of $C$. tortugae from our sites was, in contrast, unexpected because this species has been reported at sites in the U.S. Virgin Islands and Puerto Rico less than 100 miles from the BVI (Victor 2008).

Goby habitat associations were consistent with previous reports for C. glaucofraenum, but not for C. venezu- 
elae, and provide another reason why the absence of $C$. tortugae was surprising. We expected to find $C$. tortugae in Harris Ghut because it provides the type of shallow, clear-water patch reef habitat it reportedly prefers (Greenfield \& Johnson 1999; Victor 2008, 2015). Finding C. glaucofraenum only at White Bay West was in agreement with accounts of it preferring areas with fine silty sand and more turbid water (Garzón-Ferreira \& Arturo Acero 1990; Greenfield \& Johnson 1999). The fact that we found C. venezuelae at both of our protected inshore sites expands the reported habitat range for the species, which heretofore was documented to be primarily a species of deeper offshore reefs in buttress-canyon habitats and rocky points with strong currents (Victor 2015). Because we sampled just two sites, however, our data are preliminary and defining habitat associations will require additional sampling. Defining habitat preferences will also be facilitated by quantitative measurements of variables that gobies use to select habitat, such as sediment grain size, water-clarity, and substratum composition, so that cross-study comparisons can be more explicit (Baldwin \& Robertson 2015; Victor 2015; Volk et al. 2020) .

We conclude that the parasitic copepods infecting C. venezuelae, $C$. glaucofraenum and $C$. dicrus in the BVI are all P. tortugensis. COI sequence data are sparse for parasitic copepods (Boxshall \& Hayes 2019). We could find no published sequences of putative conspecifics ( $P$. tortugensis) or congeners against which to compare our samples, and sequences from confamilial taxa (family Chondracanthidae) are few. Our samples, nonetheless, cluster more closely with sequences from confamilial copepods (Chondracanthus and Acanthochondria) than with various other cyclopoid copepods (Figure 3), which is consistent with the classification of our samples within the Chondracanthidae (Østergaard et al. 2003). All copepods previously identified using morphological characters from the same hosts at the same sites were classified as $P$. tortugensis. Because this past classification was based on a fairly large sample ( 88 copepods in 2001-4 (Petrik-Finley 2005) plus 10 copepods in 2018 (G. Forrester, unpublished data)), we consider it unlikely that any other copepod species are present but not sampled.

\section{Ecological significance of pharodes-coryphopterus interactions in the BVI}

Our findings allow us to clarify an ecologically significant host-parasite interaction involving $P$. tortugensis and three abundant shared hosts in the BVI (C. venezuelae, C. glaucofraenum and C. dicrus). Surveys from 2001-2004 showed that $P$. tortugensis was widespread in the BVI and the neighbouring island of St. John in the USVI (detected at 27 of 39 sites) and that infections of these gobies were prevalent (mean $=6 \%$, range $=1-25 \%$ ) (Petrik-Finley 2005). Field and lab experiments using $C$. venezuelae and $C$. dicrus confirmed that $P$. tortugensis is transmitted directly among these hosts (Petrik-Finley 2005). Because these gobies overlap in habitat use, understanding relative rates of transmission among these newly confirmed hosts will thus be critical to define basic features of $P$. tortugensis dynamics, such as net reproductive rate of the parasite and the host density required for its persistence (Dobson 2004; Holt et al. 2003).

Past research also revealed strong impacts of $P$. tortugensis on host population dynamics in Harris Ghut (Finley \& Forrester 2003; Forrester et al. 2019; Forrester \& Finley 2006). These hosts, previously identified as C. glaucofraenum, can now be confirmed as $C$. venezuelae. Although $P$. tortugensis is sufficiently debilitating to kill some hosts directly (Finley \& Forrester 2003; Petrik-Finley 2005), its primary impact occurs by mediating the effects of predation on host gobies. All coryphopterus host species are consumed by several larger species of reef fish, and predation is the proximate cause of most goby deaths (Forrester \& Steele 2000). When threatened by predators, these gobies temporarily flee to shelter within reef crevices. For $C$. venezuelae, the scramble for access to crevices resembles the childhood game of musical chairs (Forrester \& Steele 2004; Samhouri et al. 2009; Vance et al. 2010). Infection with $P$. tortugensis compromises their ability to compete for refuges and so makes them far more vulnerable to predators than uninfected individuals (Forrester et al. 2019; Forrester \& Finley 2006). Our discovery that $P$. tortugensis also frequently infects $C$. dicrus and C. glaucofraenum broadens the scope of this interaction and makes it important to discover whether $P$. tortugensis similarly mediates vulnerability to predation for these gobies. Of particular interest is whether the three gobies compete inter-specifically, as well as intra-specifically for refuges, and whether the effects of $P$. tortugensis on competitive ability are equivalent among goby hosts.

\section{Host range of $P$. tortugensis and its relationship with other Pharodes}

Although we clarified the identities of common hosts and parasites in the BVI, considerable uncertainty remains about the host range (the number of host species infected) of P. tortugensis in the BVI and elsewhere and its relationship with the four other known species in the genus (Appendix Table 2). Copepods tend to have broader host ranges than other macroparasites of fishes (Poulin 1992) and P. tortugensis is reported from 15 host species (Table 
1). Pharodes tortugensis, P. banyulensis (Delamare Deboutteville and Nunes-Ruivo) and P. clinii (Vaney and Conte) are morphologically very similar, and both Ho (1971) and Walters (1953) speculated that variations in morphology could represent intraspecific differences. A priority for future testing with COI sequence data is, therefore, the hypothesis that $P$. tortugensis, $P$. banyulensis and $P$. clinii are actually one broadly distributed generalist species.

On the other hand, it is also possible that Pharodes includes cryptic species that lack obvious phenotypic differences. Most known hosts of $P$. tortugensis and its congeners are gobies and blennies (Appendix Table 2), which suggests they show significant co-evolution (association by descent) within these families (Paterson \& Poulin 1999). Some hosts, however, come from other fish families, such as wrasses, porgies, and scorpionfish (Table 1, Appendix Table 2). We thus hypothesize that the Pharodes most likely to be cryptic species are those occupying phylogenetically distant hosts, especially those differing in habitat use, ecology and physiology from gobies and blennies (Noble 1989). Our inability to locate additional hosts in the BVI was consistent with more thorough previous searches (Petrik-Finley 2005), suggesting that $P$. tortugensis rarely or never infects other hosts in the area. We suggest two testable hypotheses to explain this observation. First, the copepod we identified as $P$. tortugensis may be a locally abundant BVI endemic and $P$. tortugensis elsewhere in the tropical Atlantic are actually one or more different species that never reach high prevalence on any one host. Alternatively, $P$. tortugensis may be a widespread generalist parasite that, for unknown reasons, has become locally prevalent on these three coryphopterus hosts in the BVI.

\section{Acknowledgements}

We thank Lianna Jarecki, Dive BVI and the Guana Island staff for logistical support during the field work, and Elaine Shen for assistance during DNA barcoding. Funding for the project was provided by the Falconwood Foundation and the URI Division of Research \& Economic Development through a Proposal Development Grant Award.

\section{References}

Baldwin, C., Weigt, L., G Smith, D. \& H Mounts, J. (2009) Reconciling Genetic Lineages with Species in Western Atlantic Coryphopterus (Teleostei: Gobiidae). Smithsonian Contributions to the Marine Sciences, 38, 111-138.

Baldwin, C.C. \& Robertson, D.R. (2015) A new, mesophotic Coryphopterus goby (Teleostei, Gobiidae) from the southern Caribbean, with comments on relationships and depth distributions within the genus. ZooKeys, 2015, 123-142. https://doi.org/10.3897/zookeys.513.9998

Banks, J.C. \& Paterson, A.M. (2005) Multi-host parasite species in cophylogenetic studies. International journal for parasitology, 35, 741-746. https://doi.org/10.1016/j.ijpara.2005.03.003

Besansky, N.J. (1999) Complexities in the analysis of cryptic taxa within the genus Anopheles. Parassitologia, 41, 97-100.

Bickford, D., Lohman, D.J., Sodhi, N.S., Ng, P.K.L., Meier, R., Winker, K., Ingram, K.K. \& Das, I. (2007) Cryptic species as a window on diversity and conservation. Trends in Ecology \& Evolution, 22, 148-155. https://doi.org/10.1016/j.tree.2006.11.004

Bland, M. (2013) Detecting a single event. In: British Standards Institution Study Day. British Standards Institution, York, pp. 4.

Böhlke, J.E. \& Robins, C.R. (1960) A Revision of the Gobioid Fish Genus Coryphopterus. Proceedings of the Academy of Natural Sciences of Philadelphia, 112, 103-128.

Boxshall, G. \& Hayes, P. (2019) Biodiversity and Taxonomy of the Parasitic Crustacea. In: Smit, N. J., Bruce, N.L. \& Hadfield, K.A. (Eds.), Parasitic Crustacea: State of Knowledge and Future Trends. Zoological Monographs. Springer International Publishing, Cham, pp. 73-134. https://doi.org/10.1007/978-3-030-17385-2_3

Bucklin, A., Ortman, B.D., Jennings, R.M., Nigro, L.M., Sweetman, C.J., Copley, N.J., Sutton, T. \& Wiebe, P.H. (2010) A “Rosetta Stone" for metazoan zooplankton: DNA barcode analysis of species diversity of the Sargasso Sea (Northwest Atlantic Ocean). Deep Sea Research Part II: Topical Studies in Oceanography, 57, 2234-2247. https://doi.org/10.1016/j.dsr2.2010.09.025

Cervigón, F. (1994) Complemento lll Los Peces Marinos de Venezuela. 2ème Édition. Fundación Científica Los Roques, Caracas, $499 \mathrm{pp}$.

Costello, M.J. (2016) Parasite Rates of Discovery, Global Species Richness and Host Specificity. Integrative and Comparative Biology, 56, 588-599. https://doi.org/10.1093/icb/icw084

Dobson, A. (2004) Population dynamics of pathogens with multiple host species. American Naturalist, 164, S64-S78. 
https://doi.org/10.1086/424681

Finley, R. \& Forrester, G. (2003) Impact of ectoparasites on the demography of a small reef fish. Marine Ecology Progress Series 248, 305-309.

https://doi.org/10.3354/meps248305

Folmer, O., Black, M., Hoeh, W., Lutz, R. \& Vrijenhoek, R. (1994) DNA primers for amplification of mitochondrial cytochrome c oxidase subunit I from diverse metazoan invertebrates. Molecular Marine Biology and Biotechnology, 3, 294-299.

Forrester, G., Harmon, L., Helyer, J., Holden, W. \& Karis, R. (2011) Experimental evidence for density-dependent reproductive output in a coral reef fish. Population Ecology, 53, 155-163. https://doi.org/10.1007/s10144-010-0225-6

Forrester, G.E. (1995) Strong density-dependent survival and recruitment regulate the abundance of a coral reef fish. Oecologia, 103, 275-282. https://doi.org/10.1007/BF00328615

Forrester, G.E. (1999) The influence of adult density on larval settlement in a coral reef fish Coryphopterus glaucofraenum. Coral Reefs, 18, 85-89. https://doi.org/10.1007/s003380050159

Forrester, G.E., Chille, E., Nickles, K. \& Reed, K. (2019) Behavioural mechanisms underlying parasite-mediated competition for refuges in a coral reef fish. Scientific Reports, 9, 15487. https://doi.org/10.1038/s41598-019-52005-y

Forrester, G.E. \& Finley, R.J. (2006) Parasitism and a Shortage of Refuges Jointly Mediate the Strength of Density Dependence in a Reef Fish. Ecology, 87, 1110-1115. https://doi.org/10.1890/0012-9658(2006)87[1110:PAASOR]2.0.CO;2

Forrester, G.E. \& Steele, M.A. (2000) Variation in the Presence and Cause of Density-Dependent Mortality in Three Species of Reef Fishes. Ecology 81, 2416-2427. https://doi.org/10.1890/0012-9658(2000)081[2416:VITPAC]2.0.CO;2

Forrester, G.E. \& Steele, M.A. (2004) Predators, Prey Refuges, and the Spatial Scaling of Density-Dependent Prey Mortality. Ecology, 85, 1332-1342. https://doi.org/10.1890/03-0184

Garzón-Ferreira, J. \& Arturo Acero, P. (1990) Redescription of Coryphopterus tortugae (Jordan) (Osteichthyes: Gobiidae), A Valid Species of Goby from the Western Atlantic. Gulf of Mexico Science, 11 (2). [published online] https://doi.org/10.18785/negs.1102.02

Goedknegt, M.A., Thieltges, D.W., van der Meer, J., Wegner, K.M. \& Luttikhuizen, P.C. (2018) Cryptic invasion of a parasitic copepod: Compromised identification when morphologically similar invaders co-occur in invaded ecosystems. PLoS ONE, 13, e0193354. https://doi.org/10.1371/journal.pone.0193354

Greenfield, D.W. \& Johnson, R.K. (1999) Assemblage structure and habitat associations of western Caribbean gobies (Teleostei: Gobiidae). Copeia, 1999 (2), 251-266. https://doi.org/10.2307/1447470

Haydon (2002) Identifying Reservoirs of Infection: A Conceptual and Practical Challenge. Emerging Infectious Diseases, 8, $1468-1473$. https://doi.org/10.3201/eid0812.010317

Ho, J.-S. (1971) Pharodes Wilson, 1935, a genus of cyclopoid copepods (Pharodidae) parasitic on marine fishes. Journal of Natural History, 5, 349-359. https://doi.org/10.1080/00222937100770261

Holt, R.D., Dobson, A.P., Begon, M., Bowers, R.G. \& Schauber, E.M. (2003) Parasite establishment in host communities. Ecology Letters, 6, 837-842. https://doi.org/10.1046/j.1461-0248.2003.00501.x

Horton, T., Kroh, A., Ahyong, S., Bailly, N., Boyko, C.B., Brandão, S.N., Gofas, S., Hooper, J.N.A., Hernandez, F., Holovachov, O., Mees, J., Molodtsova, T.N., Paulay, G., Decock, W., Dekeyzer, S., Poffyn, G., Vandepitte, L., Vanhoorne, B., Adlard, R., Agatha, S., Ahn, K.J., Akkari, N., Alvarez, B., Anderberg, A., Anderson, G., Angel, M.V., Antic, D., Arango, C., Artois, T., Atkinson, S., Auffenberg, K., Baldwin, B.G., Bank, R., Barber, A., Barbosa, J.P., Bartsch, I., Bellan-Santini, D., Bergh, N., Bernot, J., Berta, A., Bezerra, T.N., Bieler, R., Blanco, S., Blasco-Costa, I., Blazewicz, M., Bock, P., Bonifacino de León, M., Böttger-Schnack, R., Bouchet, P., Boury-Esnault, N., Boxshall, G., Bray, R., Bruce, N.L., Cairns, S., Calvo Casas, J., Carballo, J.L., Cárdenas, P., Carstens, E., Chan, B.K., Chan, T.Y., Cheng, L., Churchill, M., Coleman, C.O., Collins, A.G., Collins, G.E., Corbari, L., Cordeiro, R., Cornils, A., Coste, M., Costello, M.J., Crandall, K.A., Cremonte, F., Cribb, T., Cutmore, S., Dahdouh-Guebas, F., Daly, M., Daneliya, M., Dauvin, J.C., Davie, P., De Broyer, C., De Grave, S., de Mazancourt, V., de Voogd, N.J., Decker, P., Decraemer, W., Defaye, D., d’Hondt, J.L., Dippenaar, S., Dohrmann, M., Dolan, J., Domning, D., Downey, R., Ector, L., Eisendle-Flöckner, U., Eitel, M., Encarnação, S.C. d., Enghoff, H., Epler, J., EwersSaucedo, C., Faber, M., Figueroa, D., Finn, J., Fišer, C., Fordyce, E., Foster, W., Frank, J.H., Fransen, C., Freire, S., Furuya, H., Galea, H., Gao, T., Garcia-Alvarez, O., Garcia-Jacas, N., Garic, R., Garnett, S., Gasca, R., Gaviria-Melo, S., Gerken, S., Gibson, D., Gibson, R., Gil, J., Gittenberger, A., Glasby, C., Glover, A., Gómez-Noguera, S.E., González-Solís, D., Gordon, D., Gostel, M., Grabowski, M., Gravili, C., Guerra-García, J.M.., Guidetti, R., Guiry, M.D., Gutierrez, D., Hadfield, K.A., 
Hajdu, E., Hallermann, J., Hayward, B.W., Heiden, G., Hendrycks, E., Herbert, D., Herrera Bachiller, A., Ho, J. s., Hodda, M., Høeg, J., Hoeksema, B., Houart, R., Hughes, L., Hyžný, M., Iniesta, L.F.M., Iseto, T., Ivanenko, S., Iwataki, M., Janssen, R., Jarms, G., Jaume, D., Jazdzewski, K., Jersabek, C.D., Jóźwiak, P., Kabat, A., Kantor, Y., Karanovic, I., Karthick, B., Katinas, L., Kim, Y.H., King, R., Kirk, P.M., Klautau, M., Kociolek, J.P., Köhler, F., Kolb, J., Kotov, A., Kremenetskaia, A., Kristensen, R.M., Kulikovskiy, M., Kullander, S., Kupriyanova, E., Lambert, G., Lazarus, D., Le Coze, F., LeCroy, S., Leduc, D., Lefkowitz, E.J., Lemaitre, R., Lichter-Marck, I.H., Lindsay, D., Liu, Y., Loeuille, B., Lörz, A.N., Lowry, J., Ludwig, T., Lundholm, N., Macpherson, E., Madin, L., Mah, C., Mamo, B., Mamos, T., Manconi, R., Mapstone, G., Marek, P.E., Marshall, B., Marshall, D.J., Martin, P., Mast, R., McFadden, C., McInnes, S.J., Meidla, T., Meland, K., Melo da Silva, D.C., Merrin, K.L., Messing, C., Mills, C., Moestrup, Ø., Mokievsky, V., Monniot, F., Mooi, R., Morandini, A.C., Moreira da Rocha, R., Morrow, C., Mortelmans, J., Mortimer, J., Musco, L., Nesom, G., Neubauer, T.A., Neubert, E., Neuhaus, B., Ng, P., Nguyen, A.D., Nielsen, C., Nishikawa, T., Norenburg, J., O’Hara, T., Opresko, D., Osawa, M., Osigus, H.J., Ota, Y., Páll-Gergely, B., Panero, J.L., Pasini, E., Patterson, D., Paxton, H., Pelser, P., Peña-Santiago, R., Perrier, V., Petrescu, I., Pica, D., Picton, B., Pilger, J.F., Pisera, A.B., Polhemus, D., Poore, G.C., Potapova, M., Pugh, P., Read, G., Reich, M., Reimer, J.D., Reip, H., Reuscher, M., Reynolds, J.W., Richling, I., Rimet, F., Ríos, P., Rius, M., Rodríguez, E., Rogers, D.C., Roque, N., Rosenberg, G., Rützler, K., Sabbe, K., Saiz-Salinas, J., Sala, S., Santagata, S., Santos, S., Sar, E., Satoh, A., Saucède, T., Schatz, H., Schierwater, B., Schilling, E., Schmidt-Rhaesa, A., Schneider, S., Schönberg, C., Schuchert, P., Senna, A.R., Serejo, C., Shaik, S., Shamsi, S., Sharma, J., Shear, W.A., Shenkar, N., Shinn, A., Short, M., Sicinski, J., Sierwald, P., Simmons, E., Sinniger, F., Sivell, D., Sket, B., Smit, H., Smit, N., Smol, N., Souza-Filho, J.F.., Spelda, J., Sterrer, W., Stienen, E., Stoev, P., Stöhr, S., Strand, M., Suárez-Morales, E., Summers, M., Suppan, L., Susanna, A., Suttle, C., Swalla, B.J., Taiti, S., Tanaka, M., Tandberg, A.H., Tang, D., Tasker, M., Taylor, J., Taylor, J., Tchesunov, A., Temereva, E., ten Hove, H., ter Poorten, J.J., Thomas, J.D., Thuesen, E.V., Thurston, M., Thuy, B., Timi, J.T., Timm, T., Todaro, A., Turon, X., Tyler, S., Uetz, P., Urbatsch, L., Uribe-Palomino, J., Urtubey, E., Utevsky, S., Vacelet, J., Vachard, D., Vader, W., Väinölä, R., Van de Vijver, B., van der Meij, S.E., van Haaren, T., van Soest, R.W., Vanreusel, A., Venekey, V., Vinarski, M., Vonk, R., Vos, C., Walker-Smith, G., Walter, T.C., Watling, L., Wayland, M., Wesener, T., Wetzel, C.E., Whipps, C., White, K., Wieneke, U., Williams, D.M., Williams, G., Wilson, R., Witkowski, A., Witkowski, J., Wyatt, N., Wylezich, C., Xu, K., Zanol, J., Zeidler, W. \& Zhao, Z. (2020) World Register of Marine Species (WoRMS). World Register of Marine Species (WoRMS). Available from: http://www.marinespecies.org (accessed 4 December 2020)

Katoh, K., Rozewicki, J. \& Yamada, K.D. (2019) MAFFT online service: multiple sequence alignment, interactive sequence choice and visualization. Briefings in Bioinformatics, 20, 1160-1166. https://doi.org/10.1093/bib/bbx108

de León, G.P.-P. \& Nadler, S.A. (2010) What We Don’t Recognize Can Hurt Us: A Plea for Awareness About Cryptic Species. Journal of Parasitology, 96, 453-464. https://doi.org/10.1645/GE-2260.1

Marshall, E. (2005) Taxonomy: Will DNA Bar Codes Breathe Life Into Classification? Science, 307, 1037-1037. https://doi.org/10.1126/science.307.5712.1037

McDonald, J.H. (2014) Handbook of Biological Statistics. $3^{\text {rd }}$ Edition. Sparky House Publishing, Baltimore, Maryland, 299 pp.

Nadler, S.A. \& De Leon, G.P.-P. (2011) Integrating molecular and morphological approaches for characterizing parasite cryptic species: implications for parasitology. Parasitology, 138, 1688. https://doi.org/10.1017/S003118201000168X

Nguyen, L.-T., Schmidt, H.A., von Haeseler, A. \& Minh, B.Q. (2015) IQ-TREE: A Fast and Effective Stochastic Algorithm for Estimating Maximum-Likelihood Phylogenies. Molecular Biology and Evolution, 32, 268-274. https://doi.org/10.1093/molbev/msu300

Noble, E.R. (1989) Parasitology: the biology of animal parasites. Lea \& Febiger, Philadelphia, Pennsylvania, 574 pp.

Østergaard, P., Boxshall, G.A. \& Quicke, D.L. (2003) Phylogeny within the Chondracanthidae (Poecilostomatoida, Copepoda). Zoologica Scripta, 32, 299-319.

https://doi.org/10.1046/j.1463-6409.2003.00113.x

Paterson, A.M. \& Poulin, R. (1999) Have chondracanthid copepods co-speciated with their teleost hosts? Systematic Parasitology, 44, 79-85.

https://doi.org/10.1023/A:1006255822947

Petrik-Finley, R.J.M. (2005) The impact of a parasitic gill copepod on the demography of a reef fish host. Ph.D., University of Rhode Island, Kingston, Rhode Island. [unknown pagination]

Poulin, R. (1992) Determinants of host-specificity in parasites of freshwater fishes. International journal for parasitology, 22, $753-758$. https://doi.org/10.1016/0020-7519(92)90124-4

Poulin, R. (2014) Parasite biodiversity revisited: frontiers and constraints. International Journal for Parasitology, 44, 581589.

https://doi.org/10.1016/j.ijpara.2014.02.003

Poulin, R. \& Keeney, D.B. (2008) Host specificity under molecular and experimental scrutiny. Trends in Parasitology, 24, $24-28$. https://doi.org/10.1016/j.pt.2007.10.002 
Poulin, R., Krasnov, B.R. \& Mouillot, D. (2011) Host specificity in phylogenetic and geographic space. Trends in Parasitology, 27, 355-361.

https://doi.org/10.1016/j.pt.2011.05.003

Robertson, D.R. \& Van Tassell, J.L. (2019) Shorefishes - Homepage. Fishes: Greater Caribbean. A guide to shorefishes of the Caribbean and adjacent areas. Version 2.0. Available from: https://biogeodb.stri.si.edu/caribbean/en/pages (accessed 21 September 2020)

Samhouri, J.F., Vance, R.R., Forrester, G.E. \& Steele, M.A. (2009) Musical chairs mortality functions: density-dependent deaths caused by competition for unguarded refuges. Oecologia, 160, 257-265. https://doi.org/10.1007/s00442-009-1307-z

Schindelin, J., Arganda-Carreras, I., Frise, E., Kaynig, V., Longair, M., Pietzsch, T., Preibisch, S., Rueden, C., Saalfeld, S., Schmid, B., Tinevez, J.-Y., White, D.J., Hartenstein, V., Eliceiri, K., Tomancak, P. \& Cardona, A. (2012) Fiji: an opensource platform for biological-image analysis. Nature Methods, 9, 676-682. https://doi.org/10.1038/nmeth.2019

Smith, M.A., Woodley, N.E., Janzen, D.H., Hallwachs, W. \& Hebert, P.D. (2006) DNA barcodes reveal cryptic host-specificity within the presumed polyphagous members of a genus of parasitoid flies (Diptera: Tachinidae). Proceedings of the National Academy of Sciences, 103, 3657-3662. https://doi.org/10.1073/pnas.0511318103

Thacker, C. \& Cole, K. (2002) Phylogeny and evolution of the gobiid genus Coryphopterus. Bulletin of Marine Science, 70 , 837-850.

Trontelj, P. \& Fišer, C. (2010) Perspectives: Cryptic species diversity should not be trivialised. Systematics and Biodiversity, 7 , $1-3$. https://doi.org/10.1017/S1477200008002909

Vance, R.R., Steele, M.A. \& Forrester, G.E. (2010) Using an individual-based model to quantify scale transition in demographic rate functions: Deaths in a coral reef fish. Ecological Modelling, 221, 1907-1921. https://doi.org/10.1016/j.ecolmodel.2010.04.014

Victor, B. (2008) Redescription of Coryphopterus tortugae (Jordan) and a new allied species Coryphopterus bol (Perciformes: Gobiidae: Gobiinae) from the tropical western Atlantic Ocean. Journal of the Ocean Science Foundation, 1, 1-19.

Victor, B.C. (2007) Coryphopterus kuna, a new goby (Perciformes : Gobiidae : Gobiinae) from the western Caribbean, with the identification of the late larval stage and an estimate of the pelagic larval duration. Zootaxa, 1526 (1), 51-61. https://doi.org/10.11646/zootaxa.1526.1.3

Victor, B.C. (2015) Western Atlantic Coryphopterus gobies. Western Atlantic Coryphopterus gobies. Available from: http:// www.coralreeffish.com/gobiidae2adult.html (accessed 21 September 2020)

Volk, D.R., Konvalina, J.D., Floeter, S.R., Ferreira, C.E.L. \& Hoffman, E.A. (2020) Going against the flow: Barriers to gene flow impact patterns of connectivity in cryptic coral reef gobies throughout the western Atlantic. Journal of Biogeography, 48 (2), 427-439. https://doi.org/10.1111/jbi.14010

Walters, V. (1953) Diocus frigidus (Copepoda; Chondracanthidae) parasitic in eelpouts at Pt. Barrow, Alaska, with notes on the species of Diocus and a revision of the diagnosis of Pharodes. The Journal of Parasitology, 39, 169-177. https://doi.org/10.2307/3274113

Ward, R.D., Hanner, R. \& Hebert, P.D. (2009) The campaign to DNA barcode all fishes, FISH-BOL. Journal of fish biology, 74, 329-356. https://doi.org/10.1111/j.1095-8649.2008.02080.x

Ward, R.D., Zemlak, T.S., Innes, B.H., Last, P.R. \& Hebert, P.D.N. (2005) DNA barcoding Australia's fish species. Philosophical Transactions of the Royal Society B: Biological Sciences, 360, 1847-1857. https://doi.org/10.1098/rstb.2005.1716

Westram, A.M., Baumgartner, C., Keller, I. \& Jokela, J. (2011) Are cryptic host species also cryptic to parasites? Host specificity and geographical distribution of acanthocephalan parasites infecting freshwater Gammarus. Infection, Genetics and Evolution, 11, 1083-1090.

https://doi.org/10.1016/j.meegid.2011.03.024 
APPENDIX TABLE 1. Genbank Accession IDs for gobies and copepods sequenced during this study. Host and parasite ID numbers allow matching of each copepod to its respective goby host.

\begin{tabular}{|c|c|c|c|}
\hline Species & Host ID & Parasite ID & GenBank Accession ID \\
\hline C. venezuelae & 6 & - & MW412102 \\
\hline C. venezuelae & 7 & - & MW412101 \\
\hline C. venezuelae & 8 & - & MW412100 \\
\hline C. venezuelae & 9 & - & MW412099 \\
\hline C. venezuelae & 10 & - & MW412098 \\
\hline C. venezuelae & 11 & - & MW412097 \\
\hline C. venezuelae & 12 & - & MW412096 \\
\hline C. venezuelae & 13 & - & MW412095 \\
\hline C. venezuelae & 15 & - & MW412094 \\
\hline C. venezuelae & 16 & - & MW412093 \\
\hline C. venezuelae & 17 & - & MW412092 \\
\hline C. venezuelae & 19 & - & MW412091 \\
\hline C. venezuelae & 20 & - & MW412090 \\
\hline C. venezuelae & 21 & - & MW412089 \\
\hline C. venezuelae & 22 & - & MW412088 \\
\hline C. venezuelae & 23 & - & MW412087 \\
\hline C. venezuelae & 25 & - & MW412086 \\
\hline C. venezuelae & 28 & - & MW412085 \\
\hline C. venezuelae & 30 & - & MW412084 \\
\hline C. venezuelae & 32 & - & MW412083 \\
\hline C. venezuelae & 37 & - & MW412082 \\
\hline C. venezuelae & 38 & - & MW412081 \\
\hline C. venezuelae & 39 & - & MW412080 \\
\hline C. venezuelae & 40 & - & MW412079 \\
\hline C. venezuelae & 41 & - & MW412078 \\
\hline C. venezuelae & 44 & - & MW412077 \\
\hline C. venezuelae & 45 & - & MW412076 \\
\hline C. venezuelae & 46 & - & MW412075 \\
\hline C. venezuelae & 48 & - & MW412074 \\
\hline C. venezuelae & 49 & - & MW412073 \\
\hline C. venezuelae & 50 & - & MW412072 \\
\hline C. venezuelae & 51 & - & MW412071 \\
\hline C. venezuelae & 52 & - & MW412070 \\
\hline C. venezuelae & 53 & - & MW412069 \\
\hline C. venezuelae & 54 & - & MW412068 \\
\hline C. venezuelae & 55 & - & MW412067 \\
\hline C. venezuelae & 56 & - & MW412066 \\
\hline C. venezuelae & 72 & - & MW412065 \\
\hline C. venezuelae & 82 & - & MW412064 \\
\hline C. venezuelae & 99 & - & MW412063 \\
\hline C. venezuelae & 107 & - & MW412062 \\
\hline C. venezuelae & 112 & - & MW412061 \\
\hline C. venezuelae & 114 & - & MW412060 \\
\hline
\end{tabular}




\begin{tabular}{|c|c|c|c|}
\hline Species & Host ID & Parasite ID & GenBank Accession ID \\
\hline C. venezuelae & 139 & - & MW412047 \\
\hline C. venezuelae & 143 & - & MW412043 \\
\hline C. glaucofraenum & 122 & - & MW412059 \\
\hline C. glaucofraenum & 124 & - & MW412058 \\
\hline C. glaucofraenum & 125 & - & MW412057 \\
\hline C. glaucofraenum & 127 & - & MW412056 \\
\hline C. glaucofraenum & 128 & - & MW412055 \\
\hline C. glaucofraenum & 129 & - & MW412054 \\
\hline C. glaucofraenum & 130 & - & MW412053 \\
\hline C. glaucofraenum & 134 & - & MW412052 \\
\hline C. glaucofraenum & 135 & - & MW412051 \\
\hline C. glaucofraenum & 136 & - & MW412050 \\
\hline C. glaucofraenum & 137 & - & MW412049 \\
\hline C. glaucofraenum & 138 & - & MW412048 \\
\hline C. glaucofraenum & 140 & - & MW412046 \\
\hline C. glaucofraenum & 141 & - & MW412045 \\
\hline C. glaucofraenum & 142 & - & MW412044 \\
\hline C. dicrus & 159 & - & MW412042 \\
\hline C. dicrus & 160 & - & MW412041 \\
\hline C. dicrus & 161 & - & MW412040 \\
\hline C. dicrus & 162 & - & MW412039 \\
\hline C. dicrus & 163 & - & MW412038 \\
\hline C. dicrus & 164 & - & MW412037 \\
\hline C. dicrus & 166 & - & MW412036 \\
\hline P. tortugensis & 6 & 1 & MW412035 \\
\hline P. tortugensis & 6 & 2 & MW412034 \\
\hline P. tortugensis & 8 & 1 & MW412033 \\
\hline P. tortugensis & 8 & 2 & MW412032 \\
\hline P. tortugensis & 10 & 1 & MW412031 \\
\hline P. tortugensis & 10 & 2 & MW412030 \\
\hline P. tortugensis & 12 & 1 & MW412029 \\
\hline P. tortugensis & 12 & 2 & MW412028 \\
\hline P. tortugensis & 15 & 1 & MW412027 \\
\hline P. tortugensis & 15 & 2 & MW412026 \\
\hline P. tortugensis & 17 & 2 & MW412025 \\
\hline P. tortugensis & 19 & 1 & MW412024 \\
\hline P. tortugensis & 19 & 2 & MW412023 \\
\hline P. tortugensis & 21 & 1 & MW412022 \\
\hline P. tortugensis & 21 & 2 & MW412021 \\
\hline P. tortugensis & 23 & 1 & MW412020 \\
\hline P. tortugensis & 23 & 2 & MW412019 \\
\hline P. tortugensis & 25 & 1 & MW412018 \\
\hline P. tortugensis & 25 & 2 & MW412017 \\
\hline
\end{tabular}




\begin{tabular}{|c|c|c|c|}
\hline Species & Host ID & Parasite ID & GenBank Accession ID \\
\hline P. tortugensis & 30 & 1 & MW412016 \\
\hline P. tortugensis & 30 & 2 & MW412015 \\
\hline P. tortugensis & 37 & 1 & MW412014 \\
\hline P. tortugensis & 37 & 2 & MW412013 \\
\hline P. tortugensis & 38 & 2 & MW412012 \\
\hline P. tortugensis & 39 & 1 & MW412011 \\
\hline P. tortugensis & 40 & 1 & MW412010 \\
\hline P. tortugensis & 41 & 1 & MW412009 \\
\hline P. tortugensis & 44 & 1 & MW412008 \\
\hline P. tortugensis & 45 & 1 & MW412007 \\
\hline P. tortugensis & 45 & 2 & MW412006 \\
\hline P. tortugensis & 46 & 1 & MW412005 \\
\hline P. tortugensis & 46 & 2 & MW412004 \\
\hline P. tortugensis & 48 & 1 & MW412003 \\
\hline P. tortugensis & 48 & 2 & MW412002 \\
\hline P. tortugensis & 49 & 1 & MW412001 \\
\hline P. tortugensis & 49 & 2 & MW412000 \\
\hline P. tortugensis & 50 & 1 & MW411999 \\
\hline P. tortugensis & 50 & 2 & MW411998 \\
\hline P. tortugensis & 51 & 1 & MW411997 \\
\hline P. tortugensis & 52 & 1 & MW411996 \\
\hline P. tortugensis & 52 & 2 & MW411995 \\
\hline P. tortugensis & 53 & 1 & MW411994 \\
\hline P. tortugensis & 53 & 2 & MW411993 \\
\hline P. tortugensis & 54 & 1 & MW411992 \\
\hline P. tortugensis & 54 & 2 & MW411991 \\
\hline P. tortugensis & 55 & 1 & MW411990 \\
\hline P. tortugensis & 55 & 2 & MW411989 \\
\hline P. tortugensis & 56 & 1 & MW411988 \\
\hline P. tortugensis & 56 & 2 & MW411987 \\
\hline P. tortugensis & 72 & 1 & MW411986 \\
\hline P. tortugensis & 72 & 2 & MW411985 \\
\hline P. tortugensis & 122 & 1 & MW411984 \\
\hline P. tortugensis & 122 & 2 & MW411983 \\
\hline P. tortugensis & 134 & 1 & MW411982 \\
\hline P. tortugensis & 134 & 2 & MW411981 \\
\hline P. tortugensis & 137 & 1 & MW411980 \\
\hline P. tortugensis & 139 & 1 & MW411979 \\
\hline P. tortugensis & 139 & 2 & MW411978 \\
\hline P. tortugensis & 142 & 1 & MW411977 \\
\hline P. tortugensis & 142 & 2 & MW411976 \\
\hline P. tortugensis & 143 & 1 & MW411975 \\
\hline P. tortugensis & 143 & 2 & MW411974 \\
\hline
\end{tabular}


APPENDIX TABLE 1. (Continued)

\begin{tabular}{llll}
\hline Species & Host ID & Parasite ID & GenBank Accession ID \\
\hline P. tortugensis & 159 & 1 & MW411973 \\
P. tortugensis & 159 & 2 & MW411972 \\
P. tortugensis & 160 & 1 & MW411971 \\
P. tortugensis & 160 & 2 & MW411970 \\
P. tortugensis & 161 & 1 & MW411969 \\
P. tortugensis & 161 & 2 & MW411968 \\
P. tortugensis & 166 & 1 & MW411967 \\
P. tortugensis & 166 & 2 & MW411966 \\
\hline
\end{tabular}

APPENDIX TABLE 2. Known hosts of other Pharodes species (Horton et al. 2020).

\begin{tabular}{llll}
\hline Parasite species & Host Family & Host species & Host common name \\
\hline Pharodes biakensis & Scorpaenidae & Caracanthus unipinna & coral croucher \\
Pharodes banyulensis. & Blenniidae & Salaria pavo & peacock blenny \\
Pharodes banyulensis. & Gobiidae & Deltentosteus quadrimaculatus & four-spotted goby \\
Pharodes clini & Clinidae & Clinitrachus argentatus & cline \\
Pharodes clini & Labridae & Symphodus ocellatus & ocellated wrasse \\
Pharodes ninnii & Gobiidae & Gobius auratus & golden goby \\
Pharodes ninnii & Gobiidae & Knipowitschia panizzae & Adriatic dwarf goby \\
\hline
\end{tabular}

